\title{
Characterization of Arsenic contaminated Rice (Oryza Sativa L.) through RAPD Markers
}

\author{
Biswarup Mukherjee ${ }^{1 *}$, Pritam Das ${ }^{1}$, Tathagata Roy Chaudhuri ${ }^{2}$ and \\ Tapash Dasgupta ${ }^{1}$ \\ ${ }^{I}$ Department of Genetics and Plant Breeding, Institute of Agricultural Science, University of Calcutta , 51/2 \\ Hazra Road, Kolkata-700019 \\ ${ }^{2}$ Department of Botany, Asutosh College, 92, S P Mukherjee Road, Kolkata 700026
}

\begin{abstract}
Rice being cultivated under anaerobic condition is vulnerable to arsenite, a mobile arsenic speciation Both arsenate and arsenite are highly toxic to human body. Experiments were conducted in Nonaghata (Nadia) and De-ganga (North 24 parganas) with 40 genotypes of rice in Boro season. A few varieties have been identified with low arsenic. Simultaneously some of them were characterized at molecular level by RAPD technique. It is worth to be seen how the low grain and high grain arsenic varieties behave in RAPD fingerprinting. Fourteen out of the 18 decamer random primers showed amplification of genomic DNA in all individuals. A total of 59 fragments were scored, of these fragments, 10 (16.94\%) were common to all accessions, 49 (83.06\%) were polymorphic and shared by at least eight accessions. It is interesting to mention that the genotypes Azucena and Lemont have already been identified as low grain arsenic genotypes and occupied a distinct different cluster for all primers at the molecular level also. More research is needed in arsenic research in crop plants in different agro climatic situation to have a meaningful and stable conclusion so that the farmers and also the people of West Bengal do not suffer from arsenic hazards at least from the consumption of rice.
\end{abstract}

Key Words: Arsenic, Genetic diversity, RAPD, Rice

\section{Introduction}

Recently, the environmental fate and behaviour of arsenic has received increasing attention due to crisis in South-East-Asia specially West Bengal and Bangladesh. Arsenic contamination in ground water has turned into the gravest natural disaster with spatial extent encompassing Bangladesh (Fazal et al., 2001; Smith et al., 2000; Hopenhayn, 2006), West Bengal (India) (Chowdhury et al., 2000), China, Taiwan, Vietnam, United States of America, Argentina, Chile, Mexico (O’Neill, 1995; Smedley and Kinniburgh, 2002). In Bangladesh, arsenic concentration in groundwater has exceeded the safe level $(0.05 \mathrm{mg} \mathrm{L}-1$ is the Bangladesh standard) in 59 districts out of 64 and about 80 million people are exposed to arsenic poisoning. Tens of millions of people have been exposed to high levels of arsenic in ground water (Christen, 2001) Up to 1000000 tube wells drilled into Ganges alluvial deposits may be contaminated with arsenic with concentration with $1000 \mu \mathrm{g}$ per liter in West Bengal.

Compared with other cereals (wheat, barley and maize) rice accumulates much higher levels of As in the shoots and grain (Duxbury and Panaullah 2007 Williams et al 2007b). For example the As transfer factor, i.e., (shoot As)/(soil As), was found to be near 1 for rice compared with 0.1-0.2 for wheat and barley (Williams et al. 2007b). The focus needs to reduce the uptake and accumulation of inorganic As in rice plants either by breeding or engineering. Current opinion voiced at a recent international meeting (20th New Phytologist Symposium Arsenic: Unraveling its metabolism and speciation in plants, University of Aberdeen June 2008), highlighted the fact that even a 10\% reduction in rice grain arsenic could save hundreds of thousands or even millions of lives.

Mead (2005) observed that As does not directly interact with DNA. Instead, the effects of As occur through indirect alteration of gene expression via disruption of DNA methylation, inhibition of DNA repair, oxidative stress, or altered modulation of signal transduction pathways. Thus toxicity of arsenate compounds (particularly at low doses) is apparently dependent on exposure to other toxic cofactors such as malnutrition, ultraviolet ray exposure., So deficiency, reduced animal protein intake, marginal Ca status, and folate deficiency (Gamble et al., 2005; Cohen et al., 2006).

More recently, DNA markers have been reliably used in cultivar identification (Moser and Lee, 1994), diversity analysis (Vasconcelos et al., 1996), construction of genetic maps (Song et al., 1991) and tagging agronomical important genes (Kelly, 1995). The development of molecular marker techniques in fact offered a direct method to estimate genetic diversity within and among population. Recently molecular techniques have become popular tools in plant systematic and phylogenetic studies (Judd et al., 1999; Sinclair et al., 1980). 
Nucleic acid markers gained popularity around 1970, with the use of restriction fragment length polymorphism. Polymerase chain reaction (PCR) was then introduced in the late 1980's (Saiki and Mahna, 1989) and DNA amplification becomes straightforward. However, they are expensive, time consuming, technically difficult (Paran and Michelmore, 1993a) and also involve some risk as radioactivity is used for their development. DNA can be used reliably in cultivar identification (Moser and Lee, 1994), diversity analysis (Vasconcelos et al., 1996), construction of genetic maps (Song et al., 1991; Price and Tomas, 1996). Molecular marker possesses ideal characteristics, since they analyze genetic diversity at the DNA level, are not affected by environmental effects, and are available in an almost unlimited number.

Present investigation aims at to estimate genetic variation in the genotypes of some rice genotypes using RAPD technique for future use in selection, hybridization, biodiversity assessment, evaluation and conservation of diverse gene pools.

\section{Materials And Methods}

Plant materials: Present study was conducted in Nonaghata (Nadia) and De-ganga (North 24 parganas) with 40 genotypes of rice procured from different research station of India (CRRI, Cuttack, Assam) and abroad (IRRI Philippines and Cornell University, USA) in Boro season. These include some genotypes which have been identified as susceptible and some of them are tolerant for arsenic uptake. It is worth to be seen how the low grain and high grain arsenic varieties behave in RAPD fingerprinting.

DNA extraction from plant samples: Two young leaves $(100 \mathrm{mg})$ were taken from each of the plant. They were carefully washed under sterile distilled water to get rid of all potential sources of contamination and DNA extraction was done by using QIAGEN plant DNA extraction kit.

PCR reaction for amplification by RAPD markers: Template DNA (20 ng) from all accessions were amplified in the presence of $100 \mathrm{ng}$ of primer (Genei, Bangalore) 1unit of Taq polymerase enzyme (Genei, Bangalore), 1x enzyme buffer, $3 \mu \mathrm{l}$ dNTPs (Genei, Bangalore) all in a total reaction volume of $25 \mu \mathrm{l}$. A total of 10 different decamer random primers were selected for the amplification of all DNA samples used in the sample. Amplifications were performed in $0.2 \mathrm{ml} \mathrm{PCR}$ tubes in a thermal cycler: $94^{\circ} \mathrm{C}$ for $5 \mathrm{~min}$ of initial denaturation followed by 36 cycles each of denaturation at $94^{\circ} \mathrm{C}$ for $30 \mathrm{sec}$, annealing at $36^{\circ} \mathrm{C}$ for $30 \mathrm{sec}$ and polymerization at $72^{\circ} \mathrm{C}$ for $1.5 \mathrm{~min}$. After the last cycle the samples were incubated for an additional $5 \mathrm{~min}$ at $72^{\circ} \mathrm{C}$ until they were analyzed. PCR reactions were carried out in a Mastercycler of Eppendorf (Model No. Mastercycler 5333 49615). All reactions were performed thrice and only reproducible bands were taken into consideration for analysis.

\section{Results And Discussion}

All the genotypes have been previously tested for arsenic tolerance (Norton et al.2009) from which twelve rice genotypes was initially examined by eighteen primers. Fourteen primers amplified and exhibited distinct fragments in most of all the genotypes. Four primers produced either smear background without distinct fragments or very complicated pattern to score making the score difficult.

Fourteen primers out of eighteen were useful primers as they were polymorphic in nature and used in evaluating the genotypes (Table: 1). A total of 59 fragments were scored. Of these fragments, 10 (16.94\%) were common to all accessions, $49(83.06 \%)$ were polymorphic and shared by at least eight accessions.

The dendrogram were constructed using the UVP Life science Software and it revealed that in general the genotypes formed four clusters in for all primers. The genotypes Azucena, Nipponbare and Lemont shared a separate cluster. It may happen as all of them belong to Tropical japonica group having different genetic background as compared to indica types. The Indica genotypes were distributed in three different clusters. The genotypes Nayanmoni and Khitish always shared a same cluster which indicates there may be some close genetic similarities present between these two genotypes.

It is interesting to mention that the genotypes Azucena and Lemont have already been identified as low grain arsenic genotypes (Norton et al 2009) and Nayanmoni have been identified as a high arsenic uptake genotype at both locations and they occupied distinct different clusters at the molecular level also. So question comes in mind whether it is possible to discriminate the uptake ability of arsenic in grain through study of genetic markers or not. The present investigation is a preliminary experiment in this direction. In order to have a more comprehensive study to predict the uptake capacity of arsenic through molecular markers it is needed to include RM markers and SNP markers extensively as RAPD markers sometimes are not reproducible. 


\section{Tables And Figures}

Table: 1 RAPD primers with corresponding bands scored and their size range together with polymorphic bands observed in rice genotypes

\begin{tabular}{|c|c|c|c|c|c|c|}
\hline $\begin{array}{c}\text { Serial } \\
\text { No. }\end{array}$ & $\begin{array}{c}\text { Primer } \\
\text { Codes }\end{array}$ & Sequences 5'-3' & $\begin{array}{c}\text { Annealing } \\
\left.\text { Temp( }{ }^{\circ} \mathbf{C}\right)\end{array}$ & $\begin{array}{c}\text { Molecular } \\
\text { Weight } \\
(\mathbf{g} / \mathbf{m o l})\end{array}$ & $\begin{array}{c}\text { No. of } \\
\text { Polymorphic } \\
\text { Band }\end{array}$ & $\begin{array}{c}\text { No. of } \\
\text { Monomorphic } \\
\text { Band }\end{array}$ \\
\hline I & OPA-01 & CAGGCCCTTC & 34 & 2964 & 2 & - \\
\hline II & OPA-02 & TGCCGAGCTG & 34 & 3044 & 4 & 1 \\
\hline III & OPA-05 & AGGGGTCTTG & 32 & 3099 & 2 & 1 \\
\hline IV & OPA-07 & GAAACGGGTG & 32 & 3117 & 2 & - \\
\hline V & OPA-08 & GTGACGTAGG & 32 & 3108 & 5 & - \\
\hline VI & OPA-10 & GTGATCGCAG & 32 & 3068 & 3 & 1 \\
\hline VII & OPA-11 & CAATCGCCGT & 32 & 2988 & 2 & - \\
\hline VIII & OPA-12 & TCGGCGATAG & 32 & 3068 & 5 & 2 \\
\hline IX & OPA-13 & CAGCACCCAC & 34 & 2942 & 3 & - \\
\hline X & OPA-14 & TCTGTGCTGG & 32 & 3050 & 4 & - \\
\hline XI & OPA-15 & TTCCGAACCC & 32 & 2948 & 3 & 1 \\
\hline XIII & OPA-18 & AGGTGACCGT & 32 & 3068 & 3 & 2 \\
\hline XVI & OPB-01 & GTTTCGCTCC & 32 & 2970 & 2 & \\
\hline XVIII & OPB-03 & CATCCCCCTG & 34 & 2924 & 8 & \\
\hline
\end{tabular}

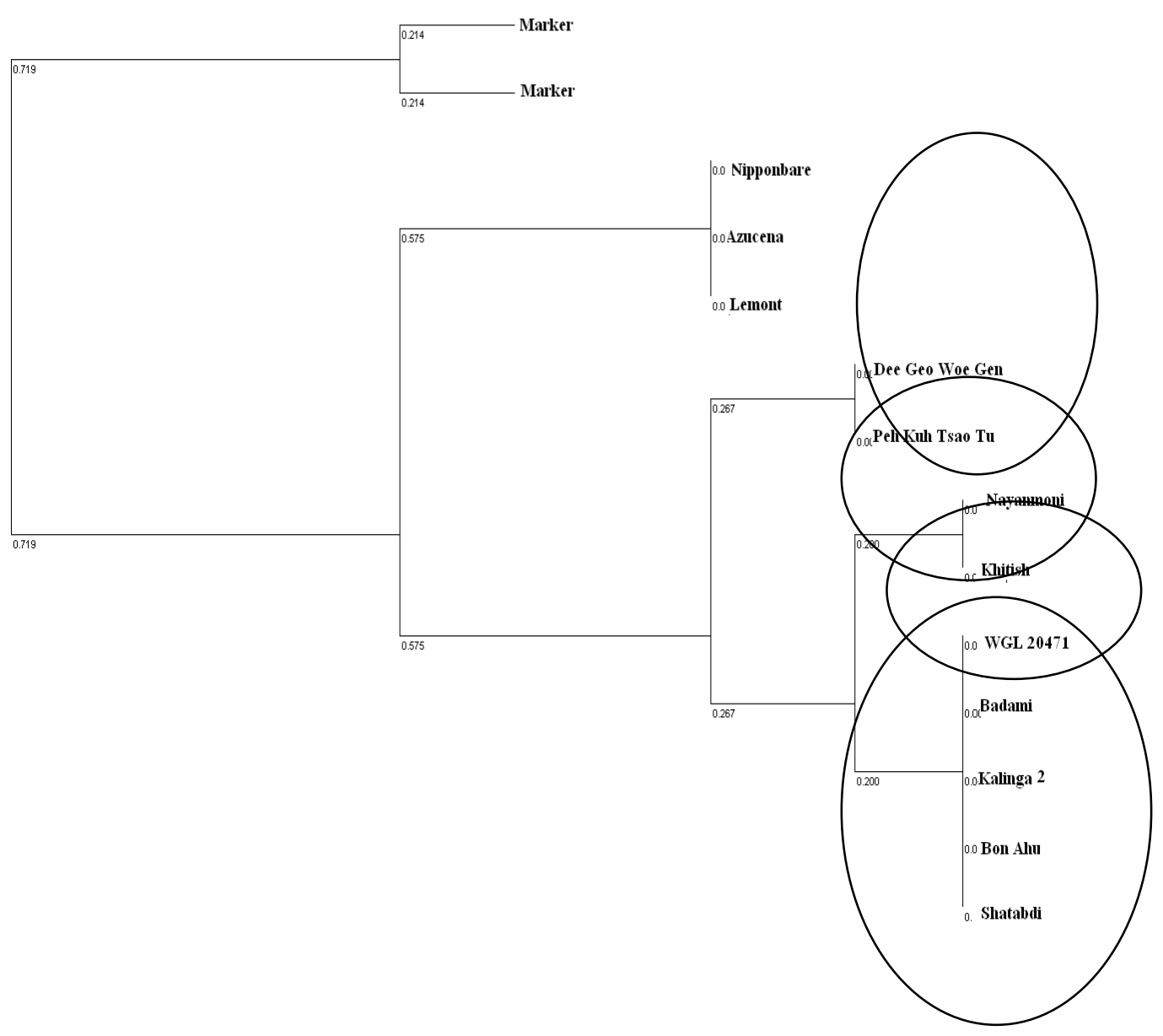




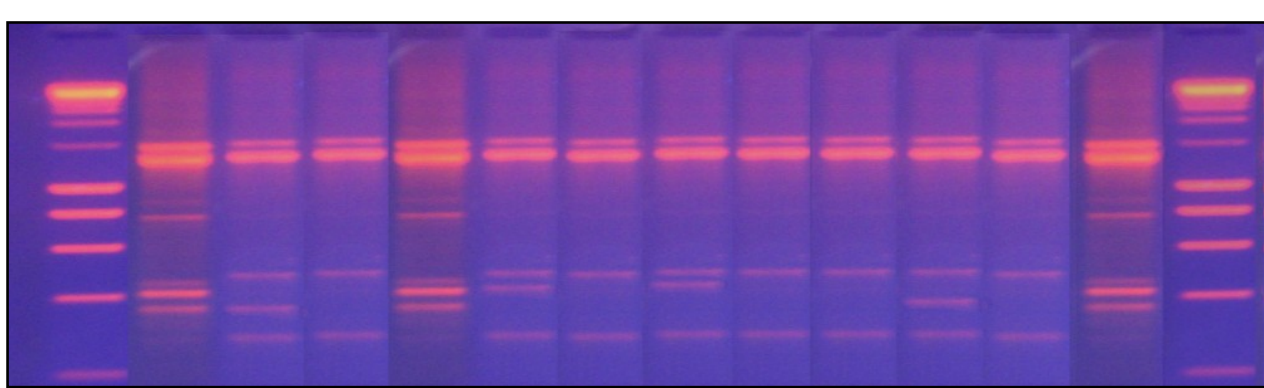

Figure B: RAPD analysis with primer $X$

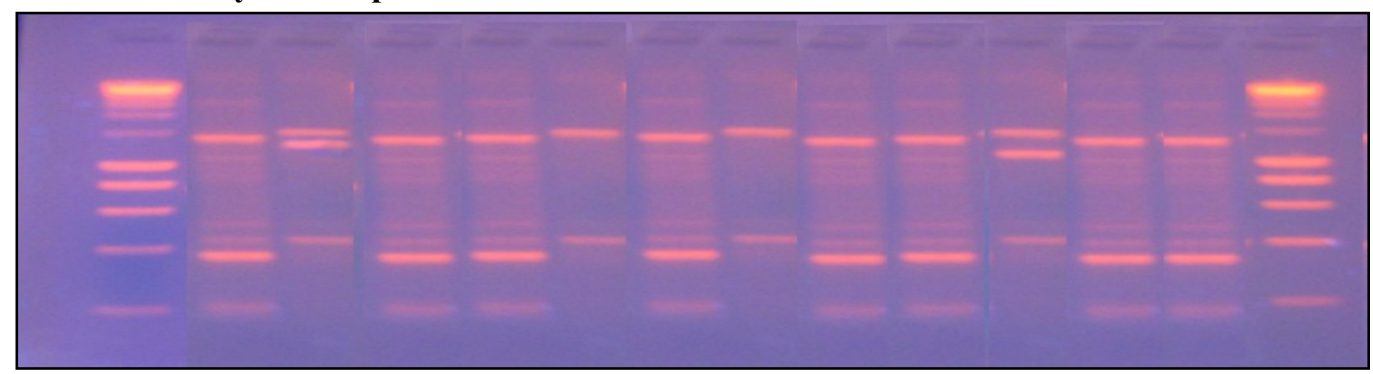

Figure C: RAPD analysis with primer V

Amplification products from genomic DNAs of 12 accessions rice using a, primer OPA-14 (Fig B) and primer OPA-08(Fig C). The lanes represent, M-molecular weight size marker, 1- Azucena, 2-KalingaII, 3Bon Ahu, 4- Lemont, 5- WGL 20471, 6-Khitish, 7-Nayanmon, 8-Badami, 9-Dee Geo Woe Gen 45, 10Shatabdi, 11-Peh Kuh Tsao Tu, 12-Nipponbare,

\section{Conclusion}

It is concluded that all Japonica rice genotypes possess considerable variation in their genetic base. Genetic makeup of a crop species is not affected by environment and only expression profiles can be the targets of environment proved in present study as the landraces collected from different geographical zones grouped together on the basis of RAPD banding profiles. The landraces with wide genetic distance can be used as parents to exploit heterosis in future rice breeding programs. The rare or unique alleles observed can further been employed for marker assisted selection programs. The primers which proved more informative can be converted to sequence tagged sites (STS) and sequence characterized amplified regions (SCAR) for amplification of specific alleles which could be further utilized in rice genome analysis.

\section{Acknowledgements}

The authors would like to thank Dr. Adam Price (Department of Plant and Soil Science, School of Biological Sciences, University of Aberdeen, Aberdeen) for the estimation of Arsenic in soil and grain and provide all necessary information. We thank the International Rice Research Institute for providing the seeds of some boro rice genotypes and grateful to the Department of Agriculture, Government of West Bengal for providing fellowship and contingency support.

\section{References}

[1] Christen, K. 2001. The arsenic threat worsens. Environmental science and technology 35:286A-291A.

[2] Chowdhury, U.K., Biswas, B.K., Chowdhury, T.R., Samanta, G., Mandal, B.K., Basu, G.C., Chanda, C.R., Lodh, D., Saha, K.C., Mukherjee, S.K., Roy, S., Kabir, S., Quamruzzaman, Q., Chakraborti, D., 2000. Groundwater arsenic contamination in Bangladesh and West Bengal, India. Environ. Health Perspect. 108, 393-397.

[3] Cohen, S. M., L. L. Arnold, M. Eldan, A. S. Lewis, and B. D. Beck. 2006. Methylated arsenicals: The implications of metabolism and carcinogenicity studies in rodents to human risk assessment. Crit. Rev. Toxicol. 36:99-133.

[4] Dasgupta T, Hossain SA, Meharg AA, Price AH. 2004. An arsenate tolerance gene on chromosome 6 of rice. New Phytologist 163, 45-49.

[5] Gareth J. Norton1, Meher Nigar1, Paul N. Williams1, Tapash Dasgupta, Andrew A. Meharg1 and Adam H. Price. 2008. Ricearsenate interactions in hydroponics: a three-gene model for tolerance Journal of Experimental Botany, Vol. 59, No. 8, pp. 22772284 ,

[6] Duxbury, J. M.; Panaullah, G. Remediation of Arsenic for Agriculture Sustainability, Food Security and Health in Bangladesh;FAO Water Working Paper; FAO: Rome, 2007; p 28.

[7] Fazal, M.A., Kawachi, T., Ichio, E., 2001. Validity of the latest research findings on causes of groundwater arsenic contamination in Bangladesh. Water Int.26, 380-389. 
[8] Hopenhayn, C., 2006. Arsenic in drinking water: impact on human health. Elements 2, 103-107

[9] Gamble, M. V., X. Liu, H. Ahsan, J. R. Pilsner, V. Llievski, V. Slavkovich, F. Parvez, D. Levy, P. Factor-Litvak, and J. H. Graziano. 2005. Folate, homocysteine, and arsenic metabolism in arsenic exposed individuals in Bangladesh. Environ. Health Perspect. 113:1683-1688.

[10] Hopenhayn, C., 2006. Arsenic in drinking water: impact on human health. Elements 2, 103-107.

[11] Judd, W.S.; Campbell, C.S.; Kellog, E.A. and Stevens P.F. (1999). Plant systematics; a Phylogenetic Approach .Sinaus Associates. Inc, Sunderland, 464

[12] Kelly, J.D. (1995). Use of randomly amplified DNA markers is breeding from major gene resistance to plant pathogens. Hort. Science, 30: $461-426$.

[13] Mead, M. N. 2005. Arsenic: In search of an antidote to a global poison. Environ. Health Perspect. 113:A379-A386.

[14] Norton GJ, Lou-Hing DE, Meharg A, Price AH. Rice-arsenate interactions in hydroponics: whole genome transcriptional analysis. Journal of Experimental Botany (2008) 59

[15] Norton, G. J.; Duan, G.; Dasgupta, T.; Islam, M. R.; Lei, M.; Zhu, Y. G.; Deacon, C. M.; Moran, A. C.; Islam, S.; Zhao, F. J.; Stroud, J. L.; McGrath, S. P.; Feldmann, J.; Price, A. H.; Meharg, A. A. Environmental and genetic control of arsenic accumulation and speciation in rice grain: comparing a range ofcommoncultivars grown in contaminated sites across Bangladesh, China and India. Environ. Sci. Technol. 2009, 43, 8381-8386.

[16] Namkoong, G.; Kang, C.H. and Brouard, J.S. (1988). Tree Breeding: Principles and Strategies, Springer - Verlag, 170.

[17] O’Neill, P., 1995. Arsenic. In: Alloway, B.J. (Ed.), Heavy Metals in Soils, pp.105-121.Paran, I. and Michelmore, R.W. (1993a). Development of reliable PCR-based markers linked to downy mildew resistance genes in lettuce. Theor. Appl. Genet. 85: 985-993

[18] Price, A. and Tomos, D. (1996). Locating genes for drought resistance in upland rice. In " Plant Genome III, Abstructs of the International Conference on the status of Plant Genome Research", 70, $15-19$ Jan, (1995) at San Diego, California, USA

[19] Saiki, G.G. and Mahna, S.K. (1989). Induction of variation in mung bean. J. of Phytological Research. $2(1)$ : 61 - 68

[20] Sinclair, W.T.; Dorman, J.D. and Ennos R.A. (1980). Multiple origin of Scot Pine (Pinus syslvestris L.) in Scotland : evidence from mitrochandrial DNA Variation. Heredity. 80: 233 - 240.

[21] Smedley, P.L., Kinniburgh, D.G., 2002. A review of the source, behavior and distribution of arsenic in natural waters. Appl Geochem. 17, 517-568.

[22] Smith, A.H., Lingas, E.O., Rahman, M., 2000. Contamination of drinking water by arsenic in Bangladesh: a public health emergency. Bull. World HealthOrgan. 78, 1093-1103.

[23] Song, K.M.; Suzuki J.Y.; Slocum M.K.; Williams, P.H. and Osborn, T.C. (1991). A linkage map of Brassica napa (syn. Campestris) based on restriction fragment length polymorphism loci. Theor. Appl. Genet. $82: 296-304$

[24] Vasconcelos, M.J.V.; De Barros, E.G.; Moreira, M.A. and Vieira, C. (1996). Genetic diversity of the common bean Phaseolus vulgaris L. determined by DNA based molecular markers. Braz J. Genet. $19: 447-451$.

[25] Williams, P. N.; Villada, A.; Deacon, C.; Raab, A.; Figuerola, J.;Green, A. J.; Feldmann, J.; Meharg, A. A. 2007b. Greatly enhanced arsenic shoot assimilation in rice leads to elevated grain levels compared to wheat and barley. Environ. Sci. Technol., 41, 6854-6859. 